\title{
Comparison of nanofiltration and evaporation technologies on the storage stability of milk protein concentrates
}

\author{
Jialu Cao ${ }^{1,2}$ • Geng Wang ${ }^{1} \cdot$ Shaozong Wu ${ }^{1}$. \\ Wei Zhang ${ }^{1} \cdot$ Chang Liu ${ }^{1} \cdot$ Haimei $\mathrm{Li}^{4}$. \\ Yan $\mathrm{Li}^{3} \cdot$ Liebing Zhang ${ }^{1,2}$
}

Received: 31 March 2015 / Revised: 23 June 2015 / Accepted: 23 June 2015 /

Published online: 21 July 2015

(C) INRA and Springer-Verlag France 2015

\begin{abstract}
Milk protein concentrates (MPCs) are highly nutritional and functional products manufactured from skim milk with low lactose levels. But, solubility of MPC decreases with time and temperature of storage, which often limits their application in food industries. The aim of present study is to compare the effect of nanofiltration and evaporation technologies on the rehydration stability of milk protein concentrates during storage. The MPCs produced by evaporation and nanofilteration were stored at different temperatures $\left(25,35\right.$, and $\left.45^{\circ} \mathrm{C}\right)$ for a period of 24 weeks to observe any changes in the storage stability. The results showed that at a given storage temperature, the rehydration properties, such as solubility, viscosity, turbidity, and particle size of the nanofiltered milk protein concentrate (NF-MPC) were better compared to the same properties of the evaporated milk protein concentrate (EPMPC). In addition, the contents of soluble protein, calcium, phosphorus, and magnesium of NF-MPC were higher than that of EP-MPC. However, no significant differences were observed in the contents of soluble lactose, sodium, and potassium of EPMPC and NF-MPC during storage. The insoluble materials of MPC were mainly
\end{abstract}

Yan Li

yanyan.9999@163.com

$\triangle$ Liebing Zhang

liebzhang@gmail.com

1 College of Food Science and Nutritional Engineering, China Agricultural University, No.17, Qinghuadonglu, Haidian District, Beijing 100083, China

2 Synergetic Innovation Center of Food Safety and Nutrition, Northeast Agricultural University, Haerbin 150030, China

3 Beijing Engineering and Technology Research Center of Food Additives, Beijing Technology and Business University, Beijing 100048, China

4 China Agri-Industries Holdings Limited, Research and Development Department, Beijing 100020, China 
caseins with small amount of whey proteins and some other protein aggregates. Our results indicate that NF-MPC has better storage stability compared to EP-MPC.

Keywords Milk protein concentrate $\cdot$ Nanofiltration $\cdot$ Evaporation $\cdot$ Solubility Storage stability

\section{Introduction}

The demand of milk protein concentrate (MPC) as a functional food ingredient is increasing in recent years. One of the most important characteristics of MPC is the ratio of casein and whey protein which is similar to raw milk. As a result, MPC is widely used in food industry, including production of beverages, cheese, confectionary, yogurt, and other food products (Fang et al. 2011). To be used as a functional food ingredient, MPC powder should readily dissolve in solution upon rehydration or reconstitution (Schokker et al. 2011). Generally, the rehydration, reconstitution, or dissolution process of food powders is carried out in four steps or phases, which includes wetting of powder particles, sinking, dispersing, and completely dissolving particles in solution. The solubility is the final step of powder dissolution and is considered as a key factor for the overall reconstitution quality (Fang et al. 2008). Solubility is also one of the prerequisites of other functional properties, such as gelling, emulsifying, and foaming properties (Moughal et al. 2000; Baldwin and Truong 2007). However, the high protein content of MPC makes the rehydration and dissolution more difficult and time consuming.

It has been reported that the solubility of MPC decreases with time and temperature of storage (Anema et al. 2006; Udabage et al. 2012; Haque et al. 2010). The insoluble material of MPC formed during storage, mainly consists of casein micelles (McKenna 2000; Anema et al. 2006; Havea 2006). The release of micelles from powder particles was found to be the rate-limiting step of MPC rehydration process and was inhibited upon storage (Mimouni et al. 2010b). In addition, the association of micelles upon storage also results in reduction of MPC solubility. The insoluble material dissolves very slowly and requires much longer rehydration time for complete dissolution (Anema et al. 2006; Mimouni et al. 2009). Haque et al. (2010) observed that proteinprotein interactions may be initiated by unfolding of protein molecules that eventually affects solubility of MPC upon aging. They also suggested a link between minor protein unfolding/refolding and gradual loss of solubility upon ageing of MPC. Le et al. (2013) suggested that the major cause of protein cross-linking was due to the advanced Maillard reaction products, which could contribute to the solubility loss of milk powder during storage.

Researchers have adopted various techniques and parameters to study the rehydration properties of food powders, such as viscosity (Gaiani et al. 2006), turbidity (Gaiani et al. 2009), particle size (Beliciu and Moraru 2009), and microscope technology (Mimouni et al. 2010a). The dissolution of mineral elements, such as calcium, phosphorus, magnesium, sodium, and potassium from powder to water could effectively affect the rehydration phase of food powders (Augustin and Clarke 1991).

The solubility of MPC can be improved by various techniques, such as ultrasound, static high pressure, high shear treatment, and addition of sodium chloride (Sun et al. 
2014; Udabage et al. 2012; Augustin et al. 2012; Mao et al. 2012). But, none of them used different concentration technology to improve MPC solubility. During ultrafiltration of MPC manufacturing, the colloid calcium may decrease, and water, ions, and lactose can pass the membrane. Thus, the casein colloid will lose its stability, especially at the state of evaporation, which likely changes the structure of milk protein, and associated quality of MPC powders (Singh 2007). Thus, nanofiltration can help to improve the solubility of MPC products. Since nanofiltration allows lower temperatures, the milk proteins would be exposed to lower heat treatment, leading to less denaturation and enhanced solubility. Our previous study (Cao et al. 2015) adopted nanofiltration technology instead of traditional evaporation to produce MPC, and the results indicate nanofiltration to be an effective technology to improve the solubility of MPC.

The present study aims to compare the effect of nanofiltration and evaporation technologies on the rehydration stability of milk protein concentrates during 24 week storage. Three different temperatures $\left(25,35\right.$, and $\left.45^{\circ} \mathrm{C}\right)$ were chosen for the storage of evaporated MPC (EP-MPC) and nanofiltered MPC (NF-MPC) for up to 24 weeks. Changes in solubility, viscosity, turbidity, particle size, and dissolution ratio of MPC were investigated.

\section{Materials and methods}

\subsection{Samples}

EP-MPC and NF-MPC were produced by Yinchuan Jinhe Dairy Industry Co., LTD, Ningxia, China. Skim milk was run through ultrafiltration after pasteurized at $85^{\circ} \mathrm{C}$ for 15 s. For evaporation line, ultrafiltered milk was preheated to $75{ }^{\circ} \mathrm{C}$, and then evaporated at 67,60 , and $56{ }^{\circ} \mathrm{C}$ in the first, second, and third effect, respectively. Evaporated MPC (EP-MPC) was obtained after spray drying. For nanofiltration line, ultrafiltered milk was processed by nanofiltration, followed by spray drying to get nanofiltered MPC (NF-MPC). The flow sheet of both MPCs process is shown in Fig. 1. The average inlet and outlet temperatures during spray drying were 160 and $85^{\circ} \mathrm{C}$, respectively. The manufacturing plant was equipped with $10-\mathrm{kDa}$ cutoff, spiral-wound ultrafiltration membranes (Parker, Cleveland, $\mathrm{OH}$ ) and 200-Da cutoff, spiral-wound nanofiltration membranes (Parker, Cleveland, OH). Basic composition of both MPC powders is shown in Table 1.

The EP-MPC and NF-MPC samples were collected and packed in sterile plastic bags and stored at $4{ }^{\circ} \mathrm{C}$ until used for study. Individual MPC samples were stored in incubators set at temperatures of 25,35 , and $45{ }^{\circ} \mathrm{C}$ for up to 24 weeks.

\subsection{Rehydration procedure}

For rehydration, MPC powder was dispersed in deionized water to concentration of $5 \%(w / v)$ at $24{ }^{\circ} \mathrm{C}$ with three drops of silicone antifoaming agent. The mixture was stirred at constant speed of $3600 \mathrm{rpm}$ for $90 \mathrm{~s}$ using an electric insolubility index stirrer with a BR-116-blade propeller (Beihong Dairy Testing Equipment Co., LTD, Harbin, 


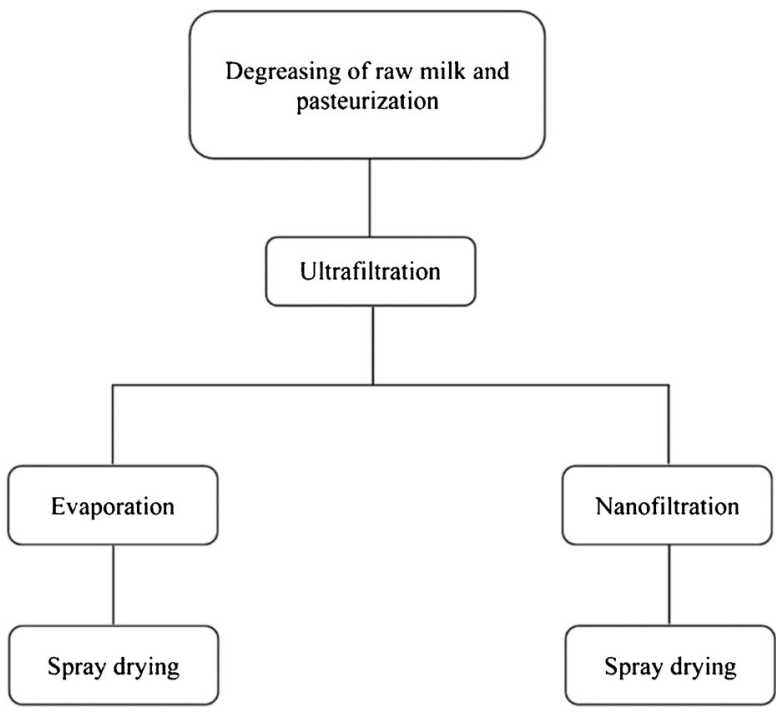

Fig. 1 The flow sheet of evaporated and nanofiltrated milk protein concentrates process

China) and kept for $10 \mathrm{~min}$ at $24{ }^{\circ} \mathrm{C}$. The resulting aqueous solution was defined as MPC rehydrated suspension (International Dairy Federation 2005).

\subsection{Insolubility index test}

The MPC rehydrated suspensions (obtained in Sect. 2.2) was gently mixed with a spatula. The suspension was poured into a $50-\mathrm{mL}$ centrifuge tube and centrifuged at $900 \mathrm{rpm}$ for $5 \mathrm{~min}$ (Pengchi Technology co., Ltd, Beijing, China). The supernatant was carefully removed with a siphon fitting until the $10-\mathrm{mL}$ mark on the centrifuge tube. Deionized water at temperature of $24^{\circ} \mathrm{C}$ was added into the tube to the $30-\mathrm{mL}$ mark, and solution was mixed prior to centrifugation ( $900 \mathrm{rpm}$ for $5 \mathrm{~min}$ ). A magnifying lens

Table 1 Composition of MPCs produced by evaporation and nanofiltration (\%)

\begin{tabular}{lll}
\hline Parameters & EP-MPC & NF-MPC \\
\hline Fat & $1.22 \pm 0.05 \mathrm{a}$ & $1.26 \pm 0.05 \mathrm{a}$ \\
Protein & $61.58 \pm 0.14 \mathrm{a}$ & $61.21 \pm 0.22 \mathrm{a}$ \\
Lactose & $28.19 \pm 0.91 \mathrm{a}$ & $28.06 \pm 0.07 \mathrm{a}$ \\
$\mathrm{Ca}$ & $1.81 \pm 0.07 \mathrm{a}$ & $1.80 \pm 0.02 \mathrm{a}$ \\
$\mathrm{P}$ & $1.39 \pm 0.03 \mathrm{a}$ & $1.35 \pm 0.02 \mathrm{a}$ \\
$\mathrm{Mg}$ & $0.13 \pm 0.00 \mathrm{a}$ & $0.13 \pm 0.00 \mathrm{a}$ \\
$\mathrm{Na}$ & $0.51 \pm 0.01 \mathrm{a}$ & $0.46 \pm 0.01 \mathrm{~b}$ \\
$\mathrm{~K}$ & $0.72 \pm 0.02 \mathrm{a}$ & $0.67 \pm 0.01 \mathrm{~b}$ \\
Water & $3.41 \pm 0.34 \mathrm{a}$ & $3.69 \pm 0.39 \mathrm{a}$ \\
\hline
\end{tabular}

Means within a row with different superscripts differ $(P<0.05)$

$E P-M P C$ evaporated milk protein concentrate, $N F-M P C$ nanofiltered milk protein concentrate 
was used to read the volume of sediment. If the volume was less than $0.5 \mathrm{~mL}$, it was read to the nearest $0.05 \mathrm{~mL}$, and if the volume was more than $0.5 \mathrm{~mL}$, it was read to $0.1 \mathrm{~mL}$. The volume of sediment was defined as the insolubility index (International Dairy Federation 2005).

\subsection{Turbidity test}

The MPC rehydrated suspensions (obtained in Sect. 2.2) were diluted ten times with deionized water. The dilution was added into a 2-mm path length quartz cuvette, and the absorbance was measured at wavelength of $860 \mathrm{~nm}$ using a JH756UV-Visible spectrophotometer (Jinghua Technology Instrument Co., Ltd, Shanghai, China) (Martin et al. 2007).

\subsection{Viscosity test}

Relative viscosity measurements of MPC rehydrated suspensions (obtained in Sect. 2.2) were performed at $60 \mathrm{rpm}$ using a digital viscometer (DV-C model) with Rotor NO.0 (Brookfield Engineering Laboratories, Inc., Middleboro, MA). MPC rehydrated suspensions $(20 \mathrm{~mL})$ were immediately transferred to the sample cup of the viscometer. Data was recorded in $30 \mathrm{~s}$ after starting the instrument (Liu et al. 2012).

\subsection{Particle size analysis}

The particle size distribution of fresh MPC powders were determined a by a S3500 computerized laser particle analyzer (Microtrac Inc., Montgomeryville, PA) using large particle mode. The particle size distribution of MPC rehydrated suspensions (obtained in Sect. 2.2) were measured by the same particle analyzer, with a presentation code that assumed the following optical parameters: a relative refractive index between the dispersed and continuous phases of 1.57 , a particle absorbance of 0.00 , and a continuous phase refractive index of 1.33 . The results of particle size were presented by $d_{50}$ (Liu et al. 2012).

\subsection{Dissolution ratio of MPC constituents}

MPC rehydrated suspensions (obtained in Sect. 2.2) and supernatant acquired after the first centrifugation (obtained in Sect. 2.3) were sampled for the determination of protein, lactose, calcium, potassium, magnesium, sodium, and phosphorus content (Wehr and Frank 2004). Briefly, protein was measured by a Kjeldahl autoanalyzer (Xinjia Electron Co., Ltd, Shanghai, China), lactose was determined by a highperformance liquid chromatography (Agilent Technologies Inc., Santa Clara, CA), and minerals were measured by an inductively coupled plasma atomic emission spectrometer (Jinhengxiang Instrument Co., Ltd, Beijing, China). Dissolution ratio was calculated according to the following equation:

Dissolution $\operatorname{ratio}(\%)=($ percentage of constituent in supernatant $) /$

(percentage of constituent in MPC rehydrated suspension) $\times 100$

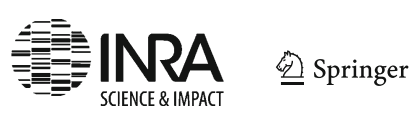


Dissolution ratio of protein and minerals mentioned above were determined at 0-, 4-, $12-$, and 24-week storage. However, dissolution ratio of lactose was determined at 0 and 24-week storage.

\subsection{SDS-PAGE analysis}

Supernatants of MPC rehydrated suspensions acquired after the first centrifugation (obtained in Sect. 2.3) were diluted twofold in $50 \mu \mathrm{L}$ loading buffer with $\beta$ mercaptoethanol (for reducing conditions) and without $\beta$-mercaptoethanol (for nonreducing conditions) (Mao et al. 2012). Then, the mixture was boiled for 5 min. Aliquots of 5- $\mu \mathrm{L}$ prepared samples were loaded into the sample well of the gel. The gel was run in a Mini-Protean Tetra system (Bio-Rad, Richmond, CA) at $120 \mathrm{~V}$ using a Model 1645070 PowerPac Universal power supply unit (Bio-Rad, Hercules, CA). The protein bands were stained using a solution of Coomassie Blue R-250. After staining and destaining of the gels, the protein bands were digitally scanned using Kodak Gel Logic 212 Imaging System (Eastman Kodak Company, Rochester, NY) (Liu et al. 2012). Each sample was analyzed at 0-, 4-, 12-, and 24-week storage.

\subsection{Statistical analysis}

All tests were conducted in triplicate, and the results were expressed as means \pm standard deviation. An analysis of variance using SPSS 17.0 software (SPSS Inc., Chicago, IL) was performed on the data. Differences were considered to be significant at $P<0.05$.

\section{Results and discussion}

\subsection{Changes in insolubility index during storage}

The rehydration process of food powder generally consists of quick wetting of powder particles, slow sinking and dispersing phases, and particles' complete solubility in solution (Fang et al. 2008; Ma 2012). Solubility is the most important property of powder rehydration since it is the last step of powder dissolution and crucial for the overall reconstitution quality (Fang et al. 2008). Changes in insolubility index of MPCs during storage are shown in Fig. 2. The insolubility index is $0.90 \mathrm{~mL}$ for fresh EP-MPC and $0.32 \mathrm{~mL}$ for NF-MPC; thus, the solubility of fresh NF-MPC is better $(P<0.05)$ than that of fresh EP-MPC. During the manufacturing of EP-MPC and NF-MPC, all unit operations were identical except for the concentration processes. The effects of evaporation and nanofiltration on the components of milk, especially milk proteins, were significantly different. The cumulative alteration of physiochemical properties of milk protein may be the main cause of this differential solubility (Cao et al. 2015). The results of insolubility index in the present study showed that solubility of MPC reduced with the increase in storage time and temperature, which are in accordance with previous studies. At the end of storage time, the insolubility index of EP-MPC was higher $(P<0.05)$ than that of NF-MPC at 25 and $35^{\circ} \mathrm{C}$ storage temperatures, and the insolubility index of both MPCs stored at $45{ }^{\circ} \mathrm{C}$ reached $11 \mathrm{~mL}$. It is clear that the 


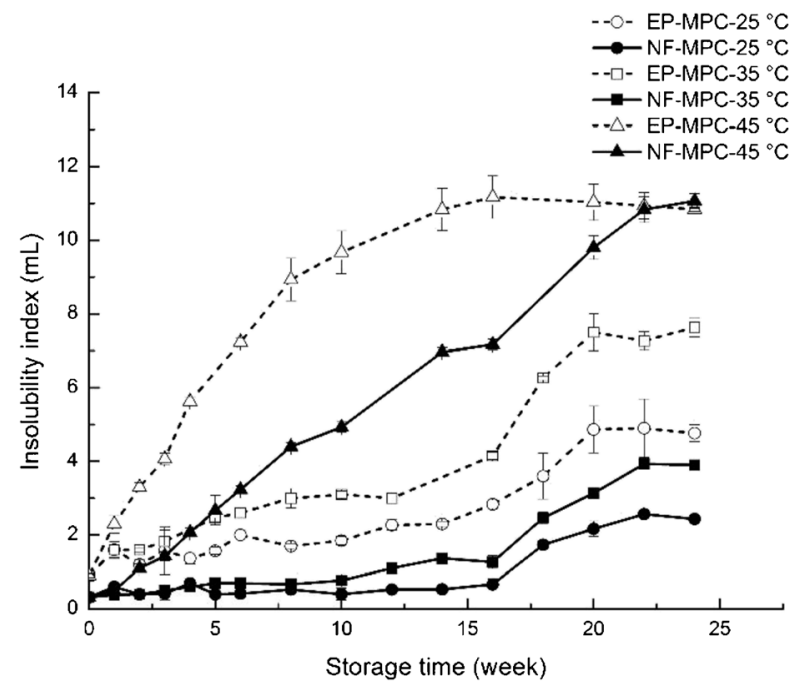

Fig. 2 Changes in insolubility index of EP-MPC and NF-MPC during storage. EP-MPC evaporated milk protein concentrate $\left(25{ }^{\circ} \mathrm{C}\right.$ (white circles), $35{ }^{\circ} \mathrm{C}$ (white squares), and $45{ }^{\circ} \mathrm{C}$ (white triangles)), $N F-M P C$ nanofiltered milk protein concentrate $\left(25{ }^{\circ} \mathrm{C}\right.$ (black circles), $35{ }^{\circ} \mathrm{C}$ (black squares), and $45{ }^{\circ} \mathrm{C}$ (black triangles))

solubility of NF-MPC was better than that of EP-MPC during storage, especially under the low storage temperatures. The loss of MPC solubility could be related to protein changes, especially caseins, and Maillard reaction during storage (Mimouni et al. 2010b; Anema et al. 2006; Le et al. 2013; Havea 2006). Therefore, to maintain low insolubility index of MPC, the storage temperature should not to exceed $35^{\circ} \mathrm{C}$ and the storage time should not be more than 4 months.

\subsection{Changes of turbidity, viscosity, and particle size during storage}

Viscosity, turbidity, and particle size are used as an indicator to predict changes in the rehydration phase of food powders. As the rehydration proceeds (from wetting to complete solution of powder particles), the values of viscosity, turbidity, and particle size gradually decrease and tend to be stabilized at the end (Donnell and Butler 1999; Ma 2012; Beliciu and Moraru 2009). It needs to be noted that all the MPC samples stored at different temperatures in this study were rehydrated within $10 \mathrm{~min}$.

The variation of turbidity and viscosity results were similar to that of insolubility index (Fig. 3a, b). The turbidity and viscosity of EP-MPC and NF-MPC were stable during the first 8 weeks, and then slowly increased over time at 25 and $35^{\circ} \mathrm{C}$. Under these conditions, the turbidity and viscosity of EP-MPC were always higher $(P<0.05)$ than that of NF-MPC. At storage temperature of $45^{\circ} \mathrm{C}$, turbidity and viscosity of the two kinds of MPCs showed a relatively high increasing rate. However, the turbidity and viscosity of EP-MPC was higher $(P<0.05)$ than NF-MPC during the earlier storage period (up to 16 weeks), but turbidity and viscosity of NF-MPC was higher $(P<0.05)$ than that of EP-MPC from 16 weeks to the end of storage time ( 24 weeks). This does not indicate insufficient rehydration property of NF-MPC at higher storage temperature. Because more sediments were seen in the rehydration suspension of EP-MPC stored at 
$45^{\circ} \mathrm{C}$ than NF-MPC at the end of the storage, which probably resulted in the relative lower viscosity and turbidity of EP-MPC solution. These results indicate that the rehydration process of NF-MPC was faster than that of EP-MPC under varying conditions of storage in this study.

The $d_{50}$ of fresh EP-MPC and NF-MPC powders were $39.92 \pm 1.75$ and $41.31 \pm$ $1.48 \mu \mathrm{m}$, respectively. However, there was no significant difference between them $(P>0.05)$. This implies that the particle size of both fresh MPC powders may have little effect on solubility of MPC powders. As shown in Fig. $3 \mathrm{c}$, the $d_{50}$ of rehydrated suspensions of EP-MPC and NF-MPC stored under varying temperatures fluctuated but relatively increased during the storage. Under the same storage temperature, $d_{50}$ of EP-MPC suspensions was higher than that of NF-MPC during the first 16 weeks. But, at the end of 24-week storage time, after 10-min rehydration, $d_{50}$ of all MPC samples were almost the same, indicating a longer rehydration process after a relative long-term storage.

On the whole, the viscosity, turbidity, and particle size of each rehydrated MPC sample increased as the storage time increased. The main cause may relate to slowing down of rehydration rate of MPC during storage. The differences between the EP-MPC and NF-MPC suggest that the rehydration properties of EP-MPC were not as good as that of NF-MPC for storage at higher temperature. These effects were more pronounced at the elevated temperature storage.

\subsection{Dissolution ratio of MPC constituents during storage}

According to the report of Mimouni et al. (2010b), nonmicellar components (whey proteins, lactose, sodium, and potassium) were rapidly released (fast-dissolving), unaffected by the studied storage conditions, whereas micellar components (caseins, calcium, phosphorus, and magnesium) were slowly released (slow-dissolving) and the effect was more pronounced after storage. Our results are in accordance with these findings and show the slow-dissolving components of NF-MPC dissolved faster than that of EP-MPC.

\subsubsection{Lactose, sodium, and potassium}

There is no significant difference between lactose dissolution ratio of fresh NF-MPC and EP-MPC $(P>0.05)$, and in both cases, the lactose dissolution ratio is close to $100 \%$. After storage for 24 weeks, lactose in all the samples stored at different temperatures was almost completely dissolved. Sodium and potassium were also completely dissolved in the rehydration process of both fresh EP-MPC and NFMPC. After storage under varying conditions, the dissolution ratio of sodium and potassium fluctuated, but their dissolution ratio was more than $90 \%$ at a given rehydration time $(10 \mathrm{~min})$ in this study. These results show that sodium and potassium, as well as lactose, could be dissolved rapidly from MPC powder in to the aqueous surrounding and they were not affected by storage conditions.

\subsubsection{Protein, calcium, phosphorus, and magnesium}

The protein dissolution ratio of both NF-MPC and EP-MPC decreased as the storage time and temperature increased (Fig. 4a). The dissolution ratio of protein was higher 
Fig. 3 Changes of rehydration properties of EP-MPC and NF-MPC during storage: a turbidity, $\mathbf{b}$ viscosity, and $\mathbf{c}$ particle size $\left(d_{50}\right)$. EP-MPC evaporated milk protein concentrate $\left(25^{\circ} \mathrm{C}\right.$ (white circles), $35^{\circ} \mathrm{C}$ (white squares), and $45^{\circ} \mathrm{C}$ (white triangles)), NF-MPC nanofiltered milk protein concentrate $\left(25^{\circ} \mathrm{C}\right.$ (black circles), $35^{\circ} \mathrm{C}$ (black squares) and $45^{\circ} \mathrm{C}$ (black triangles))

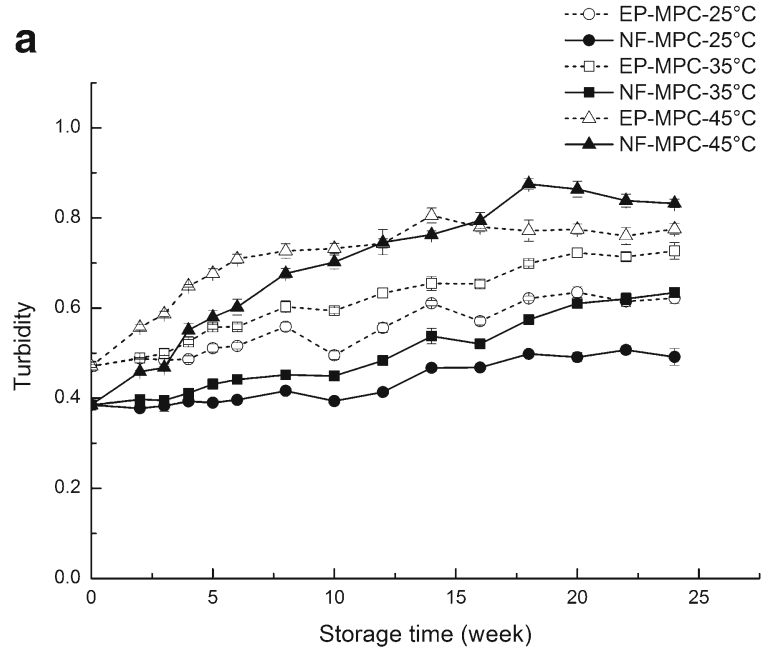

b
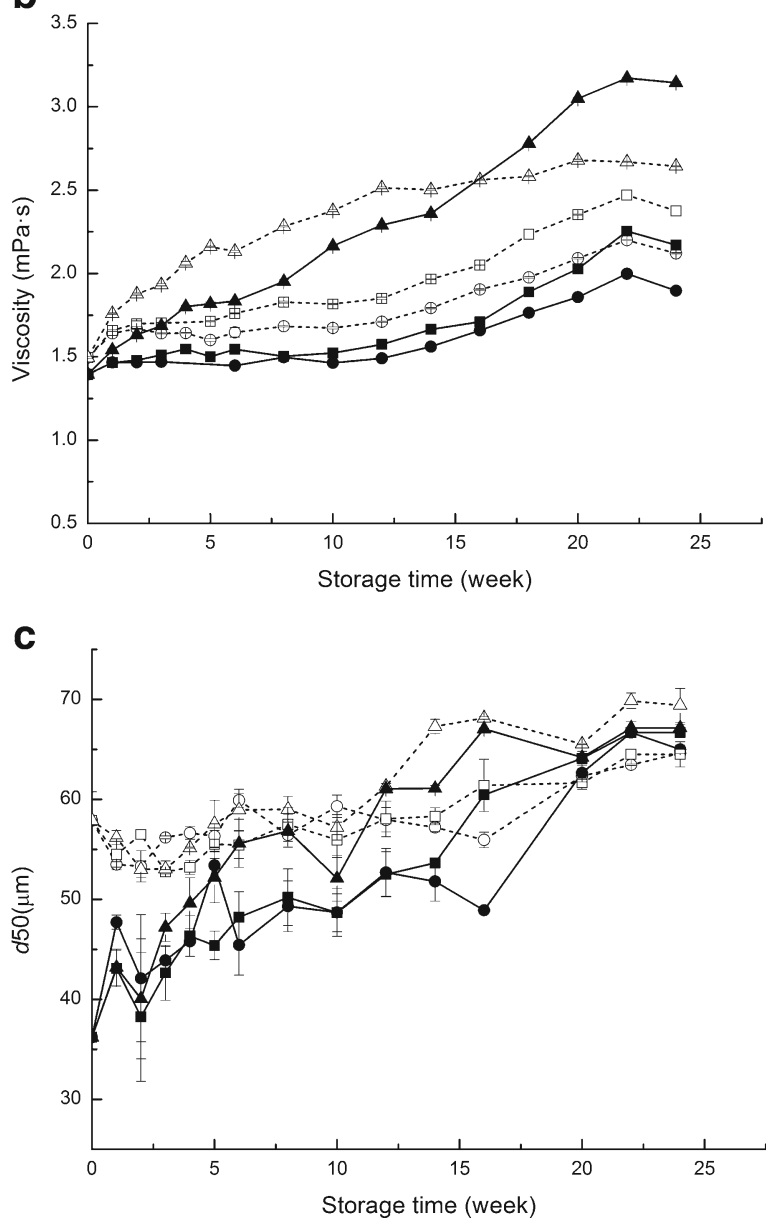

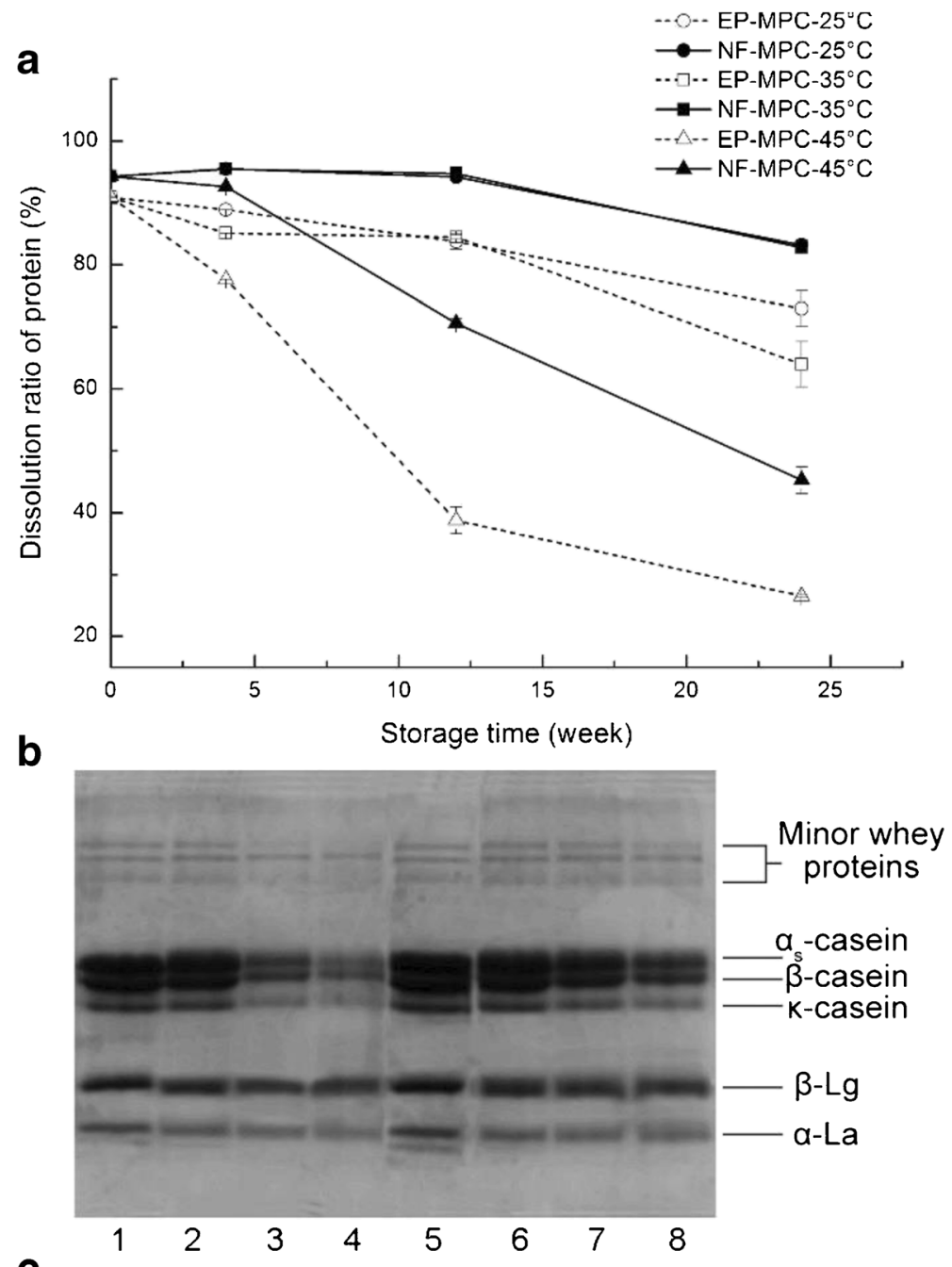

C

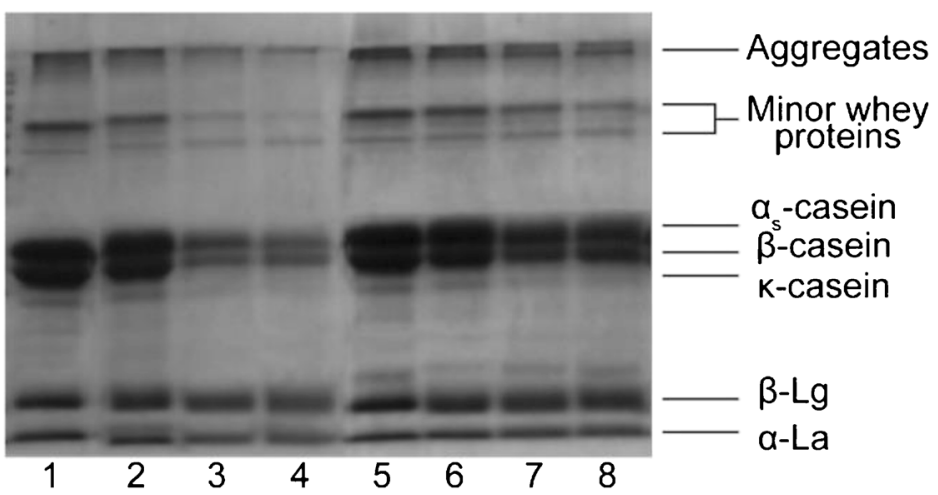


Fig. 4 Dissolution ratio and SDS-PAGE of EP-MPC and NF-MPC proteins during storage. a Dissolution ratio. EP-MPC evaporated milk protein concentrate $\left(25^{\circ} \mathrm{C}\right.$ (white circles), $35^{\circ} \mathrm{C}$ (white squares), and $45^{\circ} \mathrm{C}$ (white triangles)), MPC-NF nanofiltered milk protein concentrate $\left(25^{\circ} \mathrm{C}\right.$ (black circles), $35{ }^{\circ} \mathrm{C}$ (black squares), and $45{ }^{\circ} \mathrm{C}$ (black triangles)). b Reducing and c nonreducing SDS-PAGE of MPC supernatants during storage at $45^{\circ} \mathrm{C}$. EP-MPC, lanes 1 to 4 : fresh, 4 weeks, 12 weeks, and 24 weeks; NF-MPC, lanes 5 to 8: fresh, 4 weeks, 12 weeks, and 24 weeks

$(P<0.05)$ for MPC stored at lower temperature compared to the one stored at a higher temperature. The amount of protein dissolving in NF-MPC supernatant was higher $(P<0.05)$ than that of EP-MPC at the same storage temperature. At the end of storage, protein dissolution ratios of EP-MPC and NF-MPC decreased by 17 and $12 \%$ at $25^{\circ} \mathrm{C}$, 27 and $12 \%$ at $35{ }^{\circ} \mathrm{C}$, and 64 and $50 \%$ at $45^{\circ} \mathrm{C}$ in contrast to their corresponding fresh samples. These results suggest that storage at low temperature had less negative effects on the protein dissolution ratio. In addition, the protein dissolution ratio of NF-MPC was always higher than that of EP-MPC under the similar storage conditions.

The stored MPC was dissolved and constituents in supernatants were analyzed by reducing and nonreducing SDS-PAGE at different times during storage. Changes of soluble protein in MPC stored at $45^{\circ} \mathrm{C}$ were most obvious, so only the results at this storage temperature are shown (Fig. 4). Under reducing conditions (Fig. 4b), the $\alpha_{\mathrm{s}^{-}}$ casein, $\beta$-casein, $\mathrm{K}$-casein, and minor whey protein bands in EP-MPC and NF-MPC stored at $45^{\circ} \mathrm{C}$ become dispersed and less defined; in other words, the bands intensities decreased as the storage time increased. Furthermore, the band intensities of EP-MPC decreased much more dramatically than that of NF-MPC. This also reflected more insoluble materials (mainly casein micelles) were formed in of EP-MPC compared to NF-MPC during storage. In contrast, the major whey proteins ( $\beta$-lactoglobulin and $\alpha$ lactalbumin) in the supernatants of all the stored MPC samples did not change visually during storage, indicating that the whey proteins remained soluble. Similar results were obtained when nonreducing SDS-PAGE was performed on the supernatants of MPC stored at $45{ }^{\circ} \mathrm{C}$ (Fig. 4c). The difference between reducing and nonreducing SDSPAGE was that there were bands of aggregates which were disulfide-linked proteins on the top of the nonreducing SDS-PAGE gel. The disulfide-linked protein aggregates was considered not to play any role in the formation of insoluble material. Havea (2006) pointed out that disulfide-linked protein aggregates present in the MPC powders were not formed during storage, and these aggregates were most likely present in the initial skim milk used in the production of MPC powders. Our results confirmed that the decrease was mainly in casein in the supernatants of MPC solution, not disulfide-linked protein aggregates (Fig. 4c). However, disulfide-linked protein aggregates decreased in the supernatants of EP-MPC stored at $45^{\circ} \mathrm{C}$ as storage prolonged, while this change was not observed in the supernatants of NF-MPC (Fig. 4c). The main cause could be the interaction of disulfide-linked protein aggregates with casein micelles. In addition, the prolonged storage and the higher temperature promoted this interaction. Centrifugation of insoluble caseins with these disulfide-linked protein aggregates from the supernatants decreased the intensity of disulfide-linked protein aggregates in supernatant of EP-MPC stored at $45{ }^{\circ} \mathrm{C}$ compared to NF-MPC. These results indicate that the casein micelles of EP-MPC were less stable compared to NF-MPC.

The dissolution ratios of calcium, phosphorus, and magnesium of fresh NF-MPC were 7.55, 7.90, and $4.55 \%$ higher $(P<0.05)$ than those of fresh EP-MPC, respectively (Fig. $5 \mathrm{a}-\mathrm{c})$. The dissolution ratio of these three mineral elements in NF-MPC and EP- 
Fig. 5 Dissolution ratio of calcium, phosphorus, and magnesium of EP-MPC and NF-MPC during storage. a Calcium, b phosphorus, and $\mathbf{c}$ magnesium. EP-MPC evaporated milk protein concentrate $\left(25^{\circ} \mathrm{C}\right.$ (white circles), $35^{\circ} \mathrm{C}$ (white squares), and $45^{\circ} \mathrm{C}$ (white triangles)); NF-MPC nanofiltered milk protein concentrate $\left(25^{\circ} \mathrm{C}\right.$ (black circles), $35^{\circ} \mathrm{C}$ (black squares), and $45^{\circ} \mathrm{C}$ (black triangles))
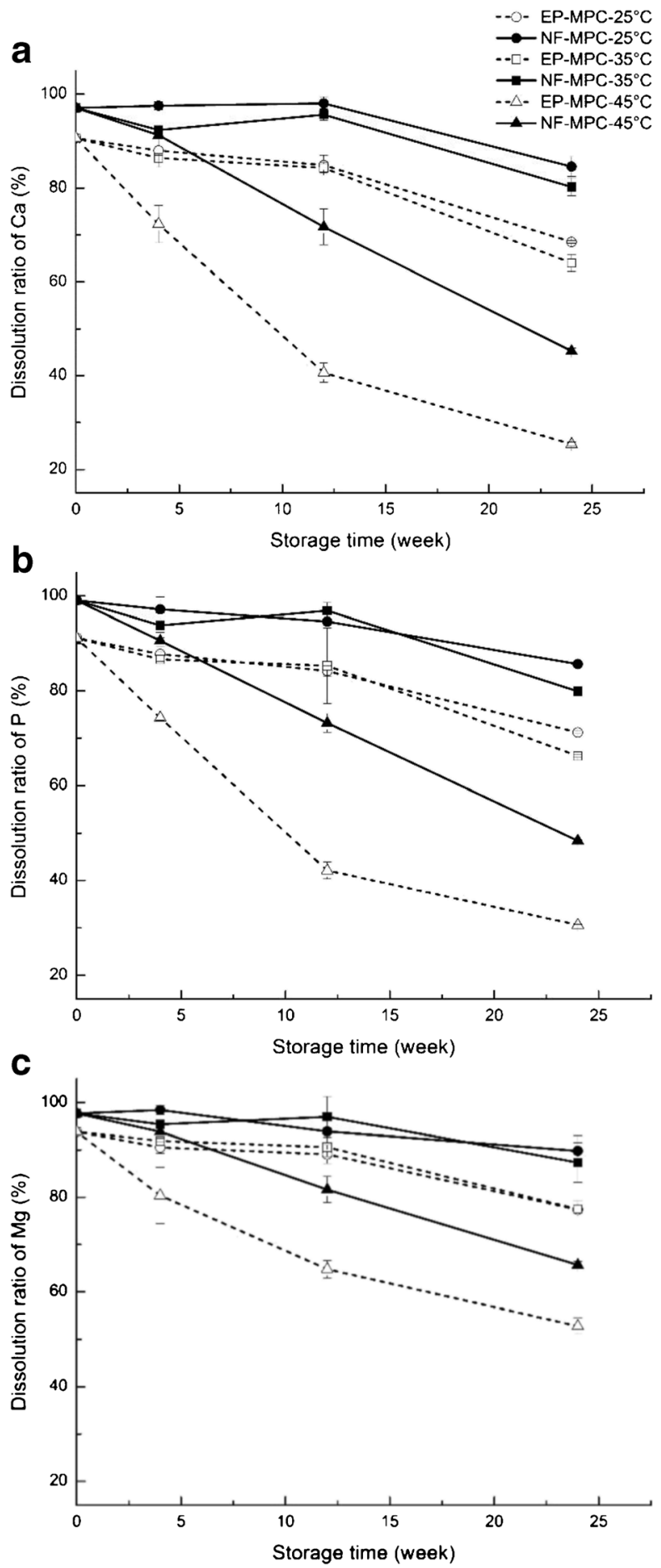
MPC decreased with the increase in storage temperature and time. Under similar storage temperature, the dissolving ratio of calcium, phosphorus, and magnesium in NF-MPC supernatant was higher $(P<0.05)$ than that of EP-MPC. These results implied that the release of these three elements into the liquid phase under certain rehydration conditions was not instantaneous and reduced after storage. Moreover, the dissolution of these minerals is closely related to that of protein, especially calcium and phosphorus. The similarities between the variation tendencies of slow-dissolving minerals and protein suggest that they follow the same kinetics of dispersion with further alteration upon storage. Our findings confirmed that slow-dissolving species belong to the casein micelle structure. Therefore, decrease in the solubility of MPC mainly attributed to the slow release of micelles from the powder particles, which was further affected by storage (Mimouni et al. 2010b). In addition, a higher storage temperature could accelerate these changes. Our results are similar to the findings of Anema et al. (2006). The mechanism of micelle association or protein cross-linking upon storage could be related to hydrophobic and/or hydrogen bonding between proteins (Anema et al. 2006; Havea 2006; Mimouni et al. 2010b) and nondisulfide covalent cross-linking (Le et al. 2012). Le et al. (2013) also reported that protein cross-linking in MPC involved advanced Maillard reaction products (e.g., methylglyoxal) during storage. Ultrafiltration can effect on the stability of milk protein during MPC manufacturing. The colloid calcium may decrease as water, ions and lactose can pass the ultrafiltration membrane. Thus, the casein colloid will lose its stability, especially when processed by heat treatment, e.g., at the state of evaporation, which likely changes the structure of milk protein, and further affects the associated properties of MPC powders (Singh 2007). Our previous research also confirmed this phenomenon and showed that less heat treatment of nanofiltration process resulted in less protein alterations. Casein micelles compactly aggregated after evaporation with higher surface hydrophobicity. But, after nanofiltration, casein micelle aggregation was not as severe as that after evaporation (Cao et al. 2015). This indicated milk protein processed by evaporation was less stable compared with that processed by nanofiltration, which may contribute to less protein-protein interaction or cross-linking caused by Maillard reaction resulting in better dissolution ratios of micelle constituents and solubility of NF-MPC even after storage at $45^{\circ} \mathrm{C}$.

\section{Conclusion}

The rehydration of MPC deteriorated with the prolonged storage at high temperatures. The MPC concentrated by the nanofiltration process showed better rehydration properties, especially solubility, and a higher dissolution ratio of micelle constituents under varying temperatures, even after 24-week storage. Adopting nanofiltration to manufacture MPC could not only improve the solubility but also enhance the storage stability of MPC. Further research is needed to evaluate and compare the functional properties of MPCs concentrated by traditional evaporation and nanofiltration for food applications.

Acknowledgments This work was supported by the National Natural Science Foundation of China (Grant No. 31171714), the Planning Subject of "the 25-year-plan" in the National Science and Technology for the Rural Development in China (2013BAD18B05-02, 2013BAD18B12-04, and 2013BAD18B12-05), the 
earmarked fund for Modern Agro-industry Technology Research System (CARS-37), Special Fund for Agroscientific Research in the Public Interest (201303085), and the National Science Foundation for Post-doctoral Scientists of China (2013M541087).

\section{References}

Anema SG, Pinder DN, Hunter RJ, Hemar Y (2006) Effects of storage temperature on the solubility of milk protein concentrate (MPC85). Food Hydrocoll 20(2-3):386-393

Augustin MA, Clarke PT (1991) Calcium ion activities of cooled and aged reconstituted and recombined milks. J Dairy Res 58(02):219-229

Augustin MA, Sanguansri P, Williams R, Andrews H (2012) High shear treatment of concentrates and drying conditions influence the solubility of milk protein concentrate powders. J Dairy Res 79(4):459-468

Baldwin AJ, Truong GNT (2007) Development of insolubility in dehydration of dairy milk powders. Food Bioprod Process 85(C3):202-208

Beliciu CM, Moraru CI (2009) Effect of solvent and temperature on the size distribution of casein micelles measured by dynamic light scattering. J Dairy Sci 92(5):1829-1839

Cao J, Zhang W, Wu S, Liu C, Li Y, Li H, Zhang L (2015) Short communication: effects of nanofiltration and evaporation on the physiochemical properties of milk protein during processing of milk protein concentrate. J Dairy Sci 98(1):100-105

Donnell SO, Butler F (1999) Viscosity of reconstituted milk protein concentrate solutions as a function of shear, temperature and concentration. Dev Chem Eng Miner Process 7(1-2):131-139

Fang Y, Selomulya C, Chen XD (2008) On measurement of food powder reconstitution properties. Dry Technol 26(1):3-14

Fang Y, Selomulya C, Ainsworth S, Palmer M, Chen XD (2011) On quantifying the dissolution behaviour of milk protein concentrate. Food Hydrocoll 25(3):503-510

Gaiani C, Scher J, Schuck P, Hardy J, Desobry S, Banon S (2006) The dissolution behaviour of native phosphocaseinate as a function of concentration and temperature using a rheological approach. Int Dairy $\mathrm{J}$ 16(12):1427-1434

Gaiani C, Scher J, Schuck P, Desobry S, Banon S (2009) Use of a turbidity sensor to determine dairy powder rehydration properties. Powder Technol 190(1-2):2-5

Haque E, Bhandari BR, Gidley MJ, Deeth HC, Moller SM, Whittaker AK (2010) Protein conformational modifications and kinetics of water-protein interactions in milk protein concentrate powder upon aging: effect on solubility. J Agric Food Chem 58(13):7748-7755

Havea P (2006) Protein interactions in milk protein concentrate powders. Int Dairy J 16(5):415-422

International Dairy Federation (2005) Dried milk and dried milk products - determination of insolubility index. IDF 129:2005(E). Brussels

Le TT, Deeth HC, Bhandari B, Alewood PF, Holland JW (2012) A proteomic approach to detect lactosylation and other chemical changes in stored milk protein concentrate. Food Chem 132(1):655-662

Le TT, Holland JW, Bhandari B, Alewood PF, Deeth HC (2013) Direct evidence for the role of Maillard reaction products in protein cross-linking in milk powder during storage. Int Dairy J 31(2):83-91

Liu G, Li Y, Cao J, Ren D, Yuan D, Zhang L (2012) Changes of microbiological and physicochemical properties in Chinese infant formula caused by high heat treatment applied on concentrated milk. Dairy Sci Technol 92(6):719-733

Ma W (2012) The effect of rehydration conditions on the dissolving process of milk protein concentrates. China Agricultural University, Beijing

Mao XY, Tong PS, Gualco S, Vink S (2012) Effect of $\mathrm{NaCl}$ addition during diafiltration on the solubility, hydrophobicity, and disulfide bonds of $80 \%$ milk protein concentrate powder. J Dairy Sci 95(7):34813488

Martin GJ, Williams RP, Dunstan DE (2007) Comparison of casein micelles in raw and reconstituted skim milk. J Dairy Sci 90(10):4543-4551

McKenna AB (2000) Effect of processing and storage on reconstitution properties of whole milk and ultrafiltered skim milk powders. Massey University, Palmerston North

Mimouni A, Deeth HC, Whittaker AK, Gidley MJ, Bhandari BR (2009) Rehydration process of milk protein concentrate powder monitored by static light scattering. Food Hydrocoll 23(7):1958-1965 
Mimouni A, Deeth HC, Whittaker AK, Gidley MJ, Bhandari BR (2010a) Investigation of the microstructure of milk protein concentrate powders during rehydration: alterations during storage. J Dairy Sci 93(2):463472

Mimouni A, Deeth HC, Whittaker AK, Gidley MJ, Bhandari BR (2010b) Rehydration of high-proteincontaining dairy powder: slow- and fast-dissolving components and storage effects. Dairy Sci Technol 90(2-3):335-344

Moughal KI, Munro PA, Singh H (2000) Suspension stability and size distribution of particles in reconstituted, commercial calcium caseinates. Int Dairy J 10(10):683-690

Schokker EP, Church JS, Mata JP, Gilbert EP, Puvanenthiran A, Udabage P (2011) Reconstitution properties of micellar casein powder: effects of composition and storage. Int Dairy J 21(11):877-886

Singh H (2007) Interactions of milk proteins during the manufacture of milk powders. Lait 87(4-5):413-423

Sun Y, Chen J, Zhang S, Li H, Lu J, Liu L, Uluko H, Su Y, Cui W, Ge W, Lv J (2014) Effect of power ultrasound pre-treatment on the physical and functional properties of reconstituted milk protein concentrate. J Food Eng 124:11-18

Udabage P, Puvanenthiran A, Yoo JA, Versteeg C, Augustin MA (2012) Modified water solubility of milk protein concentrate powders through the application of static high pressure treatment. J Dairy Res 79(1): 76-83

Wehr HM, Frank JF (2004) Standard methods for the examination of dairy products, 17th edn. American Public Health Association, Washington 